\title{
Impact of Working Capital Management on Financial Performance of Firms: Evidence from Pakistani Firms
}

\author{
Sarfaraz Bhutto $^{1 *}$, Zulfiqar Ali Rajper ${ }^{2}$, Ikhtiar Ali Ghumro², \\ Riaz Ahmed Mangi
}

\begin{abstract}
This study aims to investigate the impact of working capital management on the financial performance of firms. We have taken non-financial sector which is listed in Pakistan stock exchange (PSX) over the period of 2010 to 2015 . We have sampled 50 firms listed is PSX. The secondary data is being collected from the publication of State bank of Pakistan (SBP) "Financial Statement analyses of Non-financial sector listed in Pakistan stock exchange 2010-2015". Furthermore, we have used purposive sampling method to choose the selective firms in manufacturing industry of Pakistan. Moreover, Pearson correlation and multiple regression are used as data analyses techniques. The study variables consist working capital management as independent variable and financial performance as dependent variable. We have used proxies to compute independent variable like Average payment period (APP), inventory turnover (ITO), cash conversion cycle (CCC) and average collection period (ACP). Moreover, financial performance (dependent variable) measured as earnings per share (EPS), return on equity (ROE) and return on assets (ROA). It is observed in the results that there is a significant and negative impact of APP and ITO on ROA, but two independent variables CCC and ACP have significant and positive impact on ROA. Moreover, it is found that CCC, APP and ITO have significant and negative impact on ROE and EPS respectively. Last, it is observed that ACP has a significant and positive impact on ROE and EPS. The results of multiple regression investigated that the financial performance of Pakistani manufacturing firms is consistent with WCM. This study supports in managing the working capital requirements to boost firm performance in general. Moreover, specifically in the context of Pakistani manufacturing firms the study implications are significant in expansion and betterment of financial performance of firms.
\end{abstract}

Keywords: Financial Performance, Working Capital Management, Proxies

\section{Introduction}

The working capital is the difference of current assets and current liabilities. It is a controversial topic among researchers round the globe. The working capital management is regarded as short-term decision making based on current assets and current liabilities. This decision is tricky for financial managers to make an optimal

\footnotetext{
${ }^{1}$ Department of Commerce SALU, Khairpur, Pakistan

${ }^{2}$ Department of Commerce SALU, Shikarpur campus, Pakistan.

*Corresponding Author: sarfarazahmed0333@yahoo.com
} 
working capital. This decision is based on liquidity and return of a firm. Moreover, to determine the value of firm WC plays a vital role among firms. The desire of every firm regarding working capital is to overcome their short-term liabilities from their current assets. If a firm consist more current assets than its current liabilities, it should be said as good Employed Capital. Horne \& Wachowicz, (2004) stated that a best decision regarding working may uplift the value of firm. Moreover, they stated regarding manufacturing firms, that these firms mostly depend on the current assets, therefore, they should be more curious about WCM. In all the countries the output of manufacturing firms leads to many good results in the economy like better GDP rate, access for employment opportunities and more investment leads to competition which reduces the inflation rate in a country. Hence, the manufacturing industries are giving the same benefits in Pakistan. According to Pakistan Economic survey of 2014-2015. The economy is being benefited in GDP by $13.3 \%$ and in Employment by $13.8 \%$ respectively, only from the manufacturing firms. Pakistan is the leading country in Agriculture. However, after agricultural sector the manufacturing group became second largest economic sector of Pakistan. In manufacturing sectors, we have several sub heads of manufacturing concerns labelled into various economic groups like Pharmaceutical and Bio tech, Cement, Sugar, Beverages, Automobile, Textile, oil and gas, Technology and Hardware and Industrial metal and Mining. Firm's cash flow depends on the best decision regarding Employed Capital (Haq et al., 2011). According to Gitman, (1994) working capital must be in stable condition. Too much of working capital leads to issues in firms like agency cost, and too few working capital troubles a firm to borrow more from external sources or sometime firms go bankrupt. Therefore, firms should make a balance in working capital and indeed it is difficult for financial managers. Rehman \& Nasr, (2007) depicts that the Profit is the main concern of every business. Therefore, financial managers do hard to achieve a certain amount of profit. Simultaneously, managers think about the liquidity factor which is also important to run the operations of firm. However, liquidity (borrowings) leads to a certain level of cost. Therefore, firms need to set a balance among cost of liquidity, principal and profit. If managers fail to do so, it will arise certain complicated issues for firm like insolvency and bankruptcy. According to Afza \& Nazir, (2009) WC is simply the optimal setting of current assets and current liabilities. WC of firm can be achieved by subtraction of firm's current assets/short-term assets and short-term/current liabilities. The most important reason to find an optimal working capital is to understand the return structure of current assets which a firm employed. If the firm does not employ their funds appropriately, it would confront many issues in the operational cycle. In the financial management we have observed three decisions which a manager should take to maximize the value of firm. First, managers should take decision about financing in which they observe that whether to raise funds from debt or from equity. Second, managers take investment decisions both long and short-run, for the sake of long-run investment financial managers evaluate the business projects through capital budgeting and on the other hand for the management of short run projects they analyse working capital management. Third, managers take decision about dividend that whether to pay

Sukkur IBA Journal of Management and Business - SIJMB | Volume 5 No. 2 July - December 2018 @ Sukkur IBA University 
dividend or not it depends on firm's free cash flows (FCF). It simply means that Employed Capital is also important in maximizing the firm's value. An optimal Employed Capital may raise the overall value of firm (Sarniloglu and Demirgunes, 2008). Financial managers use a circular flow of operational activities, they buy on credit and set a time that when to clear the accounts payable and simultaneously, to attract the customers they also sale the goods on credit and generate the account receivable and for them they set a slightly early collection time period to satisfy their accounts payable on due time. It is hard for them to make such an on-time inventory turnover and collection which lead them in the fulfilment of their short-term borrowings (Rehman \& Nasr, 2007). However, sometimes firms face the bad debts issues and sudden low demand in goods by the substitution effect. The optimal WCM leads to the proper management of current assets to generate enough funds to satisfy the short-term obligations in a significant manner (Lazaridis \& Tryfondis, 2006). WC is a growing issue in among firms, now question arises that why WC is increasing issue and has great importance among financial managers, the answer is firms want to manage their day to day activities by managing liquidity and cost of liquidity. Therefore, Managers try to avail themselves of different opportunities to choose a best stream of cash flows which reduces the risk on bankruptcy or insolvency and best utilization of the short-term funds (Rahman and Nasr, 2007).

Contrary, having a low value of working capital can lead to shortage in funds to satisfy the current needs to support the operation, more liquid and less liquid working capital is not considerable, balanced situation is preferable to increase the financial performance of firm (Afza \& Nazir, 2009). WCM considered as life blood of firm. Working capital is the requirement of every firm whether the firm is small, medium or large, whether for profit firms or not for profit firms, simply, if an institution needs to be alive so as much they maintain better working capital more they could survive (Mukhopadhyay, 2004). Financial performance simply refers to output of money after performing all operational activities. This study measured financial performance by using proxies like return on assets (ROA), Earnings per share (EPS) and Return on equity (ROE). Furthermore, financial statements are drawn by a firm to analyse the financial performance that what a firm has done in the financial year. Therefore, it helps to understand the strength and weakness of firm's operations. Moreover, firms prepare statement of cash flow as well to manage the inflow and outflow of cash. Cash being a most liquid asset in the balance sheet, managers deal in cash management curiously to fulfil the working capital requirement and it also helps the firm to analyse and forecast the firm's financial performance. However, most of the speculators use ratio analyses technique to analyse the financial performance of firm. This paper aims to investigate that whether the impact of working capital on financial performance do exist in Pakistani manufacturing firms or there is nothing in it.

Employed Capital possess extremely great importance from the last decade. It is being observed that due to emergence of economies and the business world, the difficulty for firms in working capital management is keep on increasing day by day (Gill et al, 2010).

Sukkur IBA Journal of Management and Business - SIJMB | Volume 5 No. 2 July - December 2018 @ Sukkur IBA University 
In the same manner, Pakistan being a 23rd largest economy in the world face the same issues regarding WCM. The firms which are listed in Pakistan stock exchange have considerably low financial performance from last three years (Economic survey of Pakistan 2014-2015). However, the impact of WCM on financial performance of Pakistani firms are not been observed yet, that how much the firms are being affected from non-existence of WCM. We have taken the manufacturing firms which are listed in Pakistan stock exchange (PSX). In manufacturing sector, we have several sub heads of manufacturing concerns labelled into various economic groups like Pharmaceutical and Bio tech, Cement, Sugar, Beverages, Automobile, Textile, exploration sector (like Oil \& Gas), Technology and Hardware and Metal and Mining industries . The abovementioned economic groups are the most important economic groups; therefore, this study aims to investigate the impact of working capital on financial performance of these major economic groups.

\section{Literature Review}

This section refers to the empirical evidences from the world on the impact of Employed Capital/ WCM on financial performance of firms. In the literature of finance working capital is defined as the combination of current assets and current liabilities (CA-CL). Some of the financial experts say net working capital (Preve and Allendo, 2010). The current portion of assets refer to cash, account receivables and inventory whereas the current liabilities include accounts payables and accruals. The task of financial managers is to maximize the value of firm, therefore, they set a best mix of CA and CL to achieve that goal (Sarniloglu and Demirgunes, 2008). Gill et al, (2010) depicts that firm work hard to set a balance of working capital for the better operational growth. Furthermore, Taleb et al, (2010) investigated that the better management of working capital makes strengthen a firm regarding its financial position. As per focus on the new goal of financial management which is maximizing the wealth of shareholder, it is only possible if firm increases the value, so more the value of firm better the stock price can be (Nazir \& Afza, 2008). In the current competitive business environment, it is hard for firms to achieve a balance performance of working capital, firms try to make such policies through which they manage it in a significant manner, these problems may be raised due to deficiency in management policy structure (Ademola, 2014; Alipour, 2011, Binti et al, 2010 and Gitman, 1994). Appropriate management of working capital is important to a company's essential financial strength and the success in operational business. Therefore, many empirical studies have been investigated to analyse working capital, current research particularly focusing on the impact of WCM on the monetary performance of firms, it contributes the evidence from the Pakistani firms. Furthermore, the literature shows various studies which are being conducted in different parts of the world, this part explains in detail. If a firm decreases its cash conversion cycle, it would lead to better financial performance (Nobanee et al, (2011). It was investigated in Japan, by taking an analysis of 2123 firms which were related to non-financial sector. "Employed Capital involves some tricky decisions which may lead a firm prosper in

Sukkur IBA Journal of Management and Business - SIJMB | Volume 5 No. 2 July - December 2018 @ Sukkur IBA University 
current assets and due clearance of current liabilities and expenses (Brealey et al. 2002)". Fathi and Tavakkoli, (2009) revealed that the elements of WCM helps a firm to manage supply chain. An efficient and effective working capital of firm may enhance the firm's monetary performance (Singh and Asress, 2011). Nwankwo and Osho, (2010), depict that healthy financial performance of firm strengthen time, efficiency, goodwill and wealth of shareholder, though it is only possible if a firm does manage WC on an optimal level. Firm's value depends on the availability of free cash flows at a discount rate of weight average after tax cost of capital, more FCF refers to apt and prompt fulfilment of cost of financing, though WCM in one of the important elements in raising firm's value (Dong et al, 2010; Mansuri et al, 2012). The relationship of current operating assets with current liabilities denote to a short-term financing decision, WCM takes analyses of firm's short run stream of cash flows (Inflow \& Outflow), in nutshell WCM is helpful to take short run financing decision (odi and Solomon, 2010). Investment is nothing but a current commitment of money which gives a firm some future returns, though every investor/speculator analyse the future returns before to invest, in the same manner WCM is an investigation that at how much time firm collects inflow from their current assets to pay the short-term obligations on due time and to manage certain amount in current assets to regenerate inflows (Pouraghajan et al, 2012; Naveed et al, 2014; Napompech, 2012; Olsson et al, 2007). Moreover, Rehman \& Nasr, (2007) empirically investigated that WCM and profitability are negatively related with firm's liquidity ratio. Furthermore, Shaw, (2006) stated that efficient WC may avail more short-term investment opportunity, it simply means that the EWCM (efficient working capital management) leads to greater portion of current assets over short term liabilities which may turns the wheels of firm towards profitability. Though, more profitability pushes the firm to invest more in expansion of the existing operations and it also helps firm to entertain the firm from future expectations, like if firm consists excess profitability thus they can buy more at lower price and if they observed that the prices of the certain material (Raw material/Finished goods) will go up in future days consequently they can also buy more at cheaper rates. Deloof, (2003) added that firm's profitability is directly related to its sales. More sales lead to better profitability and vice versa, though effective WC may increase sales ratio and profitability as well. Gitman, (1994) depicts that efficient WC may enhance the value of firm, EWCM is possible firms make a greater portion of current assets over current liabilities. In 2014, an important study was conducted in Iran by Chashmsayadan et al, (2014). The study is based on the impact of Employed Capital on firm's monetary performance. The study consisted of those firms which were listed in TSE (Tehran stock exchange) in Iran following the time series data analyses over the period of 2007 to 2011. In the measurement of WCM they took Cash conversion cycle and its internal components. They investigated a significant and positive relationship between efficiency of WC and firm's profitability. They also depict that firms in strong financial position have less volatility in WCM compared to week firms. It simply suggests that appropriate management of $\mathrm{WC}$ raise the profitability ratio and may increase the financial position of firms. In support of Chashmsayadan et al, (2014) another

Sukkur IBA Journal of Management and Business - SIJMB | Volume 5 No. 2 July - December 2018 @ Sukkur IBA University 
researcher added that Pharma industry has positive and significant impact of WCM on financial performance (Gulia, 2014). They sampled 60 firms in pharma industry over the period of 5 years. Moreover, Correlation and regression analyses have been used to proof the hypotheses of that study. Another study is being conducted in Iran with the sample of 56 firms over the period of 2003-2007. The study found a significant impact of WC on firm performance. They have considered receivable collection period, payable deferral period and inventory turnover in measuring of WCM, while market to book ratio, return on equity and return on assets were taken to analyse financial performance. They investigated a positive and significant relationship between WCM and financial performance of Iranian firms. They reported that more profitability gives ways to firms to expand firm's projects. Moreover, increased profitability settles the issue of receivable collection period, if firm is strong in their profitability, thus they may reserve more in retained earnings and they can pay their deferral payments (accounts payable, accruals) on due time. The firm's WCM has a strong relationshipwith the profitability (Mobeen et al, 2011). They investigated this relationship among 65 firms listed at Karachi stock exchange (KSE) over the period of 2005-2009. Taani, (2011) depicts a significant and positive relationship between monetary performance and WCM, she further stated that the components of WC are most important in the raising of firm's value. Sharma and Kumar, (2011) added that components like average collection period (ACP), Cash conversion cycle (CCC) have a significant and positive relationship in overall financial performance of firm. In support of Sharma and kumar, (2011) another researcher Akinlo, (2011) investigated the same relationship with the sample of 95 Africans firms, he also observed better financial performances of firms if they cure ACP and CCC. Lazaridis and Tryfonidis, (2006) investigated with OLS model to check the relationship between firm's Employed Capital and firm's profitability. They sampled 131 listed firms over the period of 2001 2004, the results show that there is a significant relationship between both variables, which shows that smooth Employed Capital may increase the profitability of firm. Eljelly, (2004) investigated 136 Saudi listed firms and the results shows the significant relationship between WCM and monetary performance. Indian cement industry has a positive relationship between firm's WCM and FP (Ghosh and Maji, 2003; Rajesh et al. 2011). They selected some working capital components as a proxy measure like Net income before interest and tac (NIBIT), average collection period (ACP). Tighter cash conversion cycle is highly associated with profitability of Pakistani firms (Quereshi, 2014). The researcher investigated Pakistani non-financial sector listed in PXE, the regression and correlation techniques were used to analyse the data, the results show that that there is negative relationship of WCM on the Monetary performance of firms. Moreover, he argued that the effective WCM leads to better profitability and vice versa. Another supportive research paper found in the name of Alavinasab, (2013). He supported the negative relationship of WCM on the profitability or Financial performance of Iranian firms. He investigated 147 firms which were listed is Tehran over the period of 2005-2009. For correlation and multiple regression analyses He used $\mathrm{CCC}$ as a measure of $\mathrm{WC}$ and for financial performance he took ROE and ROA.

Sukkur IBA Journal of Management and Business - SIJMB | Volume 5 No. 2 July - December 2018 @ Sukkur IBA University 
Suitable average collection period from accounts receivables or debtors may increase the profitability of firm (Uremadu et, al. 2012). They investigated that if firm follows appropriate debtors aging schedule, thus they can increase the cash inflows which enhances firm's profitability and better WC position. Financial performance of firms depends on cash inflows, increase in cash inflows make a firm's ability to pay short term liability on time which raises the confidence level of investor and profitability also increases the confidence of stockholders because on the basis of better financial performance they expect some capital gains (Bagchi \& Khamrui, 2012). Amarjit and Biger, (2010) depict negative relationship in between firm's ACP and profitability and a positive relationship in between CCC and profitability. Padachi, (2006) investigated the inventory conversion period (ICP) has significant impact on profitability of firm, inventory being a less liquid asset takes time to be converted into cash inflow (sales), if firm sold their inventory immediately in result the profitability would be positively associated and vice versa, moreover, he observed that the ACP and CCC have also significant impact on financial performance (Profitability). The firm's value depends on the appropriate WCM (Deloof, 2003). Furthermore, he stated that firm's value increases the wealth of shareholder, simply it means that firms having more value automatically gives capital gains to stockholders, thus, in that situation stockholder would be more willing to buy the company's share and simultaneously firms would also generate equity funds to run the operations. It is possible if firm manage their WC. In the literature we have observed that the subject matter in controversial among several researchers, thus it is hard to say one statement for the WCM and monetary performance of firms. Moreover, we have observed that in the computation process of WCM researchers have used different proxies like Inventory turnover ratio (ITO), Average collection period (ACP), Cash conversion cycle (CCC) and Average payment period (APP). On the other side, in the computation of financial performance proxies like Return on Equity (ROE), Earnings before interest and tax (EBIT)/(PBIT), Return on assets (ROA) have been used. Most of the researchers have used traditional techniques like Correlation and Multiple regression analyses to analyse the intensity of relationship between WCM and MP or FP. Although, we observed that researcher have criticised the hypothesis of several studies. The main critics in the literature were (Vural et al, 2012; Uyar, 2009; Sen et al, 2009; Shaw, 2006). Some of the researchers stated that effective collection from account receivables lead a better impact on profitability of firm, while some stated that the firm's value maximization create core of intention to stockholders to invest in company. However, some researchers suggest that firm should increase the cash flow by purchasing inventories/raw material on credit to improve the cash inflows which may increase the profitability of firm, and on aggregate level it effects the overall performance of firm. Furthermore, the literature shows that the evidences of researchers are diverse in accordance of sample taken from different parts of the world, the results also varied among various industries round the globe. However, it is notion that the financial performance of firms is broadly affected by the efficient management of WC. Moreover, sampled taken in the studies are different in sense of nature and numbers of industries, some researchers considered manufacturing

Sukkur IBA Journal of Management and Business - SIJMB | Volume 5 No. 2 July - December 2018 @ Sukkur IBA University 
industries and others had chosen financial sector as well as trading concerns. It is fact that all the economic groups in an economy are important into some extent for economic growth, therefore, different sectors had been chosen to understand and resolve the issues of WCM over financial performance of firms. In the same direction this study has focused on manufacturing industry of Pakistan. In the literature we find that the impact of WC on the financial performance of manufacturing firms hasn't much studied in the case of Pakistan. However, some researches have been investigated in Pakistan i.e. (Qureshi, 2014; Malik \& Muhammad,2014; Abor \& Joshua, 2004; Mobeen et. al, 2011; Raheman \& Nasr, 2007; Ahmad et. al. 2014). Therefore, this paper adds up some supportive evidences to these studies on the basis of Pakistani manufacturing businesses while measuring impact of WCM and monetary performance. This research is representing the manufacturing sector into sub-portions of several industries. Though, in manufacturing sectors, we have several sub heads of manufacturing concerns labelled into various economic groups like Pharmaceutical and Bio tech, Cement, Sugar, Beverages, Automobile, Textile, oil and gas, Technology and Hardware and Industrial metal and Mining. This was one of the reason to do research to understand the collective results of WCM on the financial performance of these firms because in literature we have observed that the subject matter of WCM has been controversial among researchers due to the reason that firms are scattered today in shape of nature, location, political and economic situations and financial position. In that regard, some of the researchers investigated a positive correlation between WCM and FP of firms and others observed negative relationship between these two variables. This study has taken the sample of 50 manufacturing firms which are listed in PSX and the data was collected over the period of 2010-2015 to investigate the relationship between working capital management (WCM) and Financial Performance/Monetary Performance (FP/MP) of firms.

\section{Hypothesis Development \& Conceptual Framework:}

As we have observed in the literature, the results of WCM of FP are controversial among researchers. In most of the studies WCM is measured, based on ITO, APP, CCC and ACP while on the other side FP is being measure using the proxies of EPS, ROE and ROA. The literature showed a negative impact of WCM on FP. Following the results of the previous researches we have developed the hypotheses in the same direction which show a negative impact of working capital management (WCM) on Financial Performance (FP) of Pakistani manufacturing firms. Moreover, in the hypothesis development one independent variable of WCM average collection period (ACP) has found a positive association on FP. On the above grounds we have developed following hypothesis to investigate the results.

Sukkur IBA Journal of Management and Business - SIJMB | Volume 5 No. 2 July - December 2018 @ Sukkur IBA University 


\section{Hypothesis of the Study:}

H1a: CCC has a significant and positive impact on ROA.

H1b: CCC has a significant and negative impact on ROE.

H1c: CCC has a significant and negative impact on EPS.

H2a: APP has a significant and negative impact on ROA.

H2b: APP has a significant and negative impact on ROE.

H2c: APP has a significant and negative impact on EPS.

H3a: ITO has a significant and negative impact on ROA.

H3b: ITO has a significant and negative impact on ROE.

H3c: ITO has a significant and negative impact on EPS.

H4a: ACP has a significant and positive impact on ROA.

H4b: ACP has a significant and positive impact on ROE.

H4c: ACP has a significant and positive impact on EPS.

The study model (Figure-1) illustrates that the CCC, APP, ITO and ACP are considered as independent variables and Financial performance (Dependent variable) includes ROA, ROE and EPS as dependent variable Moreover, Leverage, Firm Size and Age of firm used as control variables.

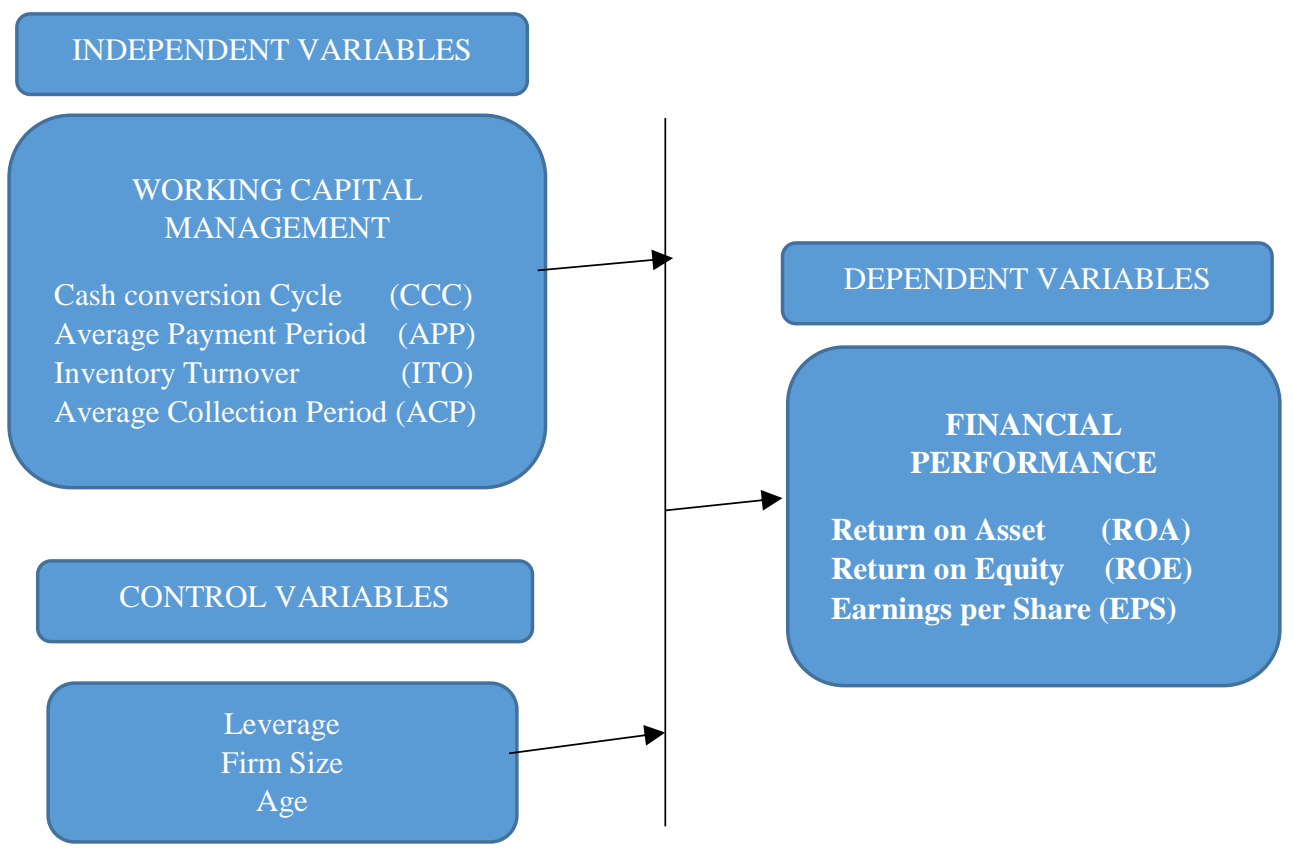

Figure 1: Conceptual Framework of the Study

Sukkur IBA Journal of Management and Business - SIJMB | Volume 5 No. 2 July - December 2018 @ Sukkur IBA University 


\section{Methodology}

This study is quantitative in nature. A population size of 50 manufacturing firms has been chosen which are listed is PSX over the period of 2010-2015. Moreover, those firms who have not submitted their annual financial report were skipped from this study. We have taken sample from the manufacturing sectors, we have several sub heads of manufacturing concerns labelled into various economic groups like Pharmaceutical and Bio tech, Cement, Sugar, Beverages, Automobile, Textile, exploration industries (like Oil and Gas), Technology and Hardware and Industrial metal and Mining. The sectors are listed in the Pakistan stock exchange (PSX). The services sector is not taken in this study because of the nature of their business. The transactions which are made by manufacturing sector are distinct to the transactions of services group. Therefore, we cannot apply the same Employed Capital policy of manufacturing concerns on services concerns. Moreover, we have used purposive sampling to select the firms from the various manufacturing sectors. This study is based on secondary data and we have collected data from the official websites of sampled manufacturing firms, some annual reports from the website of Pakistan stock exchange because all the firms are listed in the PSX, therefore it is a valid source to collect financial information, moreover, a summarized data of all manufacturing concerns is collected from the publication of State Bank of Pakistan (SBP) "Balance sheet Analyses of joint stock companies from 2010-2015". This study has used correlation and regression techniques in investigating study variables, and before drawing an inference of correlation and regression, this study has described complete data set in descriptive statistics. This study portrayed three Multiple regression models.

\section{Multiple Regression Models:}

\section{$1^{\text {st }}$ Model:}

$$
R O A=\beta_{0}+\beta_{1} C C C+\beta_{2} A P P+\beta_{3} I T O+\beta_{4} A C P+\beta_{5} L E V+\beta_{6} S Z+\beta_{7} A G+\mathscr{E}
$$

Where;

$$
\begin{aligned}
& \beta_{0}=\text { Constant Value } \\
& \text { ROA }=\text { Return on Assets } \\
& \text { CCC }=\text { Cash Conversion Cycle } \\
& \text { APP }=\text { Average Payment Period } \\
& \text { ITO } \quad=\text { Inventory Turnover } \\
& \text { ACP }=\text { Average Collection Period } \\
& \text { Lev } \quad=\text { Leverage } \\
& \text { SZ } \quad=\text { Firm's Sze }
\end{aligned}
$$


Sarfaraz Bhutto et al. Impact of Working Capital Management on Financial Performance of Firms:

Evidence from Pakistani Firms

$$
\begin{array}{ll}
\mathrm{AG} & =\text { Age of Firm } \\
\mathcal{E} & =\text { Error Term }
\end{array}
$$

$2^{\text {nd }}$ Model:

$$
R O E=\beta_{0}+\beta_{1} C C C+\beta_{2} A P P+\beta_{3} I T O+\beta_{4} A C P+\beta_{5} L E V+\beta_{6} S Z+\beta_{7} A G+\mathscr{E}
$$

Where;

$$
\begin{array}{ll}
\beta_{0} & =\text { Constant Value } \\
\text { ROE } & =\text { Return on Equity } \\
\text { CCC } & =\text { Cash Conversion Cycle } \\
\text { APP } & =\text { Average Payment Period } \\
\text { ITO } & =\text { Inventory Turnover } \\
\text { ACP } & =\text { Average Collection Period } \\
\text { Lev } & =\text { Leverage } \\
\text { SZ } & =\text { Firm's Sze } \\
\text { AG } & =\text { Age of Firm } \\
\mathcal{E} & =\text { Error Term }
\end{array}
$$

$3^{\text {rd }}$ Model:

$$
E P S=\beta_{0}+\beta_{1} C C C+\beta_{2} A P P+\beta_{3} I T O+\beta_{4} A C P+\beta_{5} L E V+\beta_{6} S Z+\beta_{7} A G+\mathscr{E}
$$

Where;

$$
\begin{aligned}
& \beta_{0}=\text { Constant Value } \\
& \text { EPS } \quad=\text { Earnings Per share } \\
& \text { CCC } \quad=\text { Cash Conversion Cycle } \\
& \text { APP }=\text { Average Payment Period } \\
& \text { ITO }=\text { Inventory Turnover } \\
& \text { ACP }=\text { Average Collection Period } \\
& \text { Lev }=\text { Leverage } \\
& \text { SZ }=\text { Firm's Sze } \\
& \text { AG }=\text { Age of Firm } \\
& \mathcal{E} \quad=\text { Error Term }
\end{aligned}
$$

Sukkur IBA Journal of Management and Business - SIJMB | Volume 5 No. 2 July - December 2018 @ Sukkur IBA University 


\section{Results And Discussions}

This section is divided into three parts. First, we explain the Proxies which were used to compute the study variables (Dependent/Independent variables). Second, whole sampled data set of manufacturing firms was summarised by the descriptive statistics and third, we have described the results of correlation and regression of the three regression models of the study. Moreover, we also suggested some questions for future research on the study topic.

Table 1: Proxy Definitions

\begin{tabular}{|c|c|c|}
\hline $\begin{array}{c}\text { Dependent \& Independent } \\
\text { variables }\end{array}$ & Description in Full & Measurement \\
\hline ROA & Return on assets & Net income after tax/Total Assets \\
\hline ROE & Return on Equity & Net income after tax/Equity \\
\hline EPS & Earnings Per Share & $\begin{array}{l}\text { Income Available for common } \\
\text { stockholders/Outstanding shares }\end{array}$ \\
\hline $\mathrm{CCC}$ & Cash Conversion Cycle & RCP+ITO-APP \\
\hline APP & Average Payment Period & $\begin{array}{l}\text { Purchase/Average a/c } \\
\text { payable } \times 365\end{array}$ \\
\hline ITO & Inventory Turnover & $\begin{array}{l}\text { Cost of goods sold/ Average } \\
\text { inventory } \times 365\end{array}$ \\
\hline $\mathrm{ACP}$ & Average collection period & $\begin{array}{l}\text { Sales/ Average a/c Receivable } \\
\times 365\end{array}$ \\
\hline LEV & Leverage & Total Debt/ Total Assets \\
\hline $\mathrm{SZ}$ & Firm Size & Natural Logarithm of total Assets \\
\hline AG & Age of Firm & $\begin{array}{l}\text { Natural log of Age (From } \\
\text { formation of firm) }\end{array}$ \\
\hline
\end{tabular}

Table 1 refers the variables column in which we can observe the study variables (Dependent/Independent variables). ROA, ROE and EPS are dependent variables to compute financial performance of the firms. Moreover, WCM includes the independent variable like CCC, APP, ITO and ACP, furthermore, we have used some control variables to draw out the appropriate results of FP these control variables are Leverage, Firm's Size and Age of firm. The second column of the above table-1 shows the full abbreviations of each variable and the last column depicts the proxy measure of all variables. The financial data of all the sampled firms are computed based on the above proxies than it was entered in the SPSS for further proceedings like descriptive statistics, correlation matrix and regression for the all three models of the study. 
Sarfaraz Bhutto et al. Impact of Working Capital Management on Financial Performance of Firms:

Table 2: Descriptive Statistics (2010-2015)

\begin{tabular}{lcccc}
\hline \multicolumn{1}{c}{ Variables } & Min & Max & Mean & St: Deviation \\
\hline ROA & 25.39 & 51.23 & 34.15 & 37.13 \\
ROE & 08.23 & 71.17 & 21.18 & 22.62 \\
EPS & 07.69 & 68.23 & 28.29 & 29.31 \\
CCC & 71.52 & 116.19 & 30.10 & 29.99 \\
APP & 31.12 & 61.11 & 24.88 & 22.56 \\
ITO & 18.00 & 58.00 & 32.19 & 34.11 \\
ACP & 33.10 & 76.18 & 38.18 & 37.14 \\
LEV & 00.12 & 02.59 & 00.60 & 00.57 \\
SZ & 04.59 & 10.66 & 07.33 & 00.46 \\
AG & 00.60 & 01.26 & 01.12 & 00.19 \\
\hline
\end{tabular}

Table 2 shows a summarised view of all the sampled data of Pakistani Manufacturing firms which are listed in PSX over the period of 2010-2015. It is a useful way to understand the whole data set in a concise manner. We included min, max, Mean and std. deviation columns in descriptive statistics. The variable ROA shows a mean value of 34.15. It represents that if company invests 1 rupee so they may generate 34.15 return on the investment in their assets. In the same manner ROE refers 21.18 return on the equity in the mean value and EPS depicts 28.29 rupees on the earnings per share. Furthermore, the mean values of CCC, APP, ITO and ACP represents the days in which firms convert assets into cash which is important for firms to run day to day operations. The CCC shows that a firm takes 30.10 days to convert their cash from inventory, collection from receivables and payable deferrals. Moreover, the average payment period shows a mean value of 24.88 days to pay their suppliers after availing credit from them. ITO and ACP show the average values of 32.19 and 38.18. ITO refers that how much time a company takes to sale their inventory but it is not necessary that firm should sale all of their inventory on cash, some of the portion of sales may be on credit, therefore, ACP measure that how many days a firm takes to collect cash from account receivables. In that regard the ITO and ACP shows an average of 32.19 days and 38.18 days respectively.

Table 3: Correlation Matrix

\begin{tabular}{|c|c|c|c|c|c|c|c|c|c|c|}
\hline Variables & ROA & ROE & EPS & $\mathrm{CCC}$ & APP & ITO & $\mathrm{ACP}$ & LEV & SZ & $\mathrm{AG}$ \\
\hline ROA & 1 & & & & & & & & & \\
\hline ROE & 0.0547 & 1 & & & & & & & & \\
\hline EPS & 0.0891 & 0.0324 & 1 & & & & & & & \\
\hline $\mathrm{CCC}$ & -0.0534 & 0.0541 & -0.0177 & 1 & & & & & & \\
\hline APP & -0.5444 & -0.0891 & 0.0398 & 0.1009 & 1 & & & & & \\
\hline ITO & -0.0472 & 0.0181 & -0.0712 & 0.0538 & 0.1206 & 1 & & & & \\
\hline $\mathrm{ACP}$ & -0.0466 & -0.0341 & 0.0281 & 0.1108 & 0.0634 & 0.0734 & 1 & & & \\
\hline LEV & 0.0522 & 0.0384 & -0.042 & -0.0334 & 0.0151 & -0.0401 & -0.6522 & 1 & & \\
\hline SZ & 0.0129 & -0.0662 & -0.0671 & -0.0172 & 0.0642 & 0.02834 & -0.1789 & -0.1831 & 1 & \\
\hline $\mathrm{AG}$ & -0.007 & 0.0686 & -0.0014 & 0.0159 & -0.1941 & 0.0611 & 0.0145 & 0.1893 & 0.0896 & 1 \\
\hline
\end{tabular}

ROA: Return on asset, ROE: Return on equity, EPS: Earning per share, ACP: Average collection period, APP:

Average payment period, ITO: Inventory turnover, CCC: Cash conversion cycle

Sukkur IBA Journal of Management and Business - SIJMB | Volume 5 No. 2 July - December 2018 @ Sukkur IBA University 
Table 3 depicts the degree of relationship between dependent and independent variables. The correlation table shows the direction of relationship between study variables. In the above table- 3 we can observe that the highest negative association is placed in between firm's leverage and average collection period (ACP) having the value of -.6522. This result shows that there is a strongly inverse relationship between Leverage and ACP. Despite of that few study variables have positive correlation and some have negative correlation but all variables carry a very less correlation. Moreover, it can be observed in the correlation table that multicollinearity does not exist in the sampled data set as all variables contains the results of less than .70 or $70 \%$.

Table 4: Regression Model-I Summary

\begin{tabular}{lcc}
\hline \multicolumn{1}{c}{ Independent Variable } & Coefficient & P value \\
\hline CCC & 0.0547 & $0.0486^{*}$ \\
APP & -0.484 & $0.0185^{* *}$ \\
ITO & -0.559 & $0.0339^{* *}$ \\
ACP & 0.589 & $0.0579^{* *}$ \\
LEV & 56.4356 & 0.3098 \\
SZ & 19.5645 & 0.1267 \\
AG & 1.9876 & 0.3278 \\
Constant & 76.9805 & 0.3456 \\
$\mathrm{R}^{2}$ & & F-Statistics \\
Adj: $\mathrm{R}^{2}$ & 0.3018 & \multicolumn{2}{c}{ Probability (F-Statistics) 0.0002}
\end{tabular}

** and * indicates significance at the $5 \%$ and $10 \%$ level respectively, CCC, APP, ITO, ACP, LEV, SZ and AG stands for Cash Conversion cycle, average payment period, inventory turnover, average collection period, leverage, Size of firm and age of firm, ROA: Return on asset, ROE: Return on equity, EPS: Earning per share.

Table 4 shows the results of 1st regression equation of this study. In this equation we concluded the impact of WCM on FP of firms. In the first regression equation we have taken Return on assets (ROA) as dependent variable. The results of P values and Fstatistics shows the model's goodness of fit. The F-Statistics is at 9.2189 and $\mathrm{P}$ values are also at their significant levels of $5 \%$ and $10 \%$ which indicates model fitness. The $\mathrm{R}^{2}$ is at .3018 or $30.18 \%$ which determined that there is $30.18 \%$ impact of independent variables on the financial performance of firms. However, the constant value is statistically insignificant which shows that there are no other factors to affect the FP of firms. Furthermore, the coefficient column shows that CCC has statistically significant and positive impact on ROA. Moreover, APP and ITO is statistically significant and negatively associated with ROA. However, ACP is significant and positively related to ROA as it was hypothesised in the study. The relative results were observed in the studies of (Majeed et al. 2013; Ali, 2011; Deloof, 2003).

Sukkur IBA Journal of Management and Business - SIJMB | Volume 5 No. 2 July - December 2018 @ Sukkur IBA University 
Sarfaraz Bhutto et al. Impact of Working Capital Management on Financial Performance of Firms:

Table 5: Regression Model-II Summary

\begin{tabular}{|c|c|c|}
\hline Independent Variable & Coefficient & $\mathrm{P}$ value \\
\hline $\mathrm{CCC}$ & -0.045 & $0.0767 *$ \\
\hline APP & -0.1609 & $0.0432 * *$ \\
\hline ITO & -0.5971 & $0.0061 *$ \\
\hline $\mathrm{ACP}$ & 0.4821 & $0.0387 * *$ \\
\hline LEV & 46.1812 & 0.1523 \\
\hline SZ & 26.7443 & 0.8109 \\
\hline AG & 2.9873 & 0.9984 \\
\hline Constant & 903.6176 & 0.1567 \\
\hline 0.3178 & F-Statistics & 10.8822 \\
\hline Adj: $R^{2}$ & Probability & 0.0003 \\
\hline
\end{tabular}

** and * indicates significance at the 5\% and $10 \%$ level respectively, CCC, APP, ITO, ACP, LEV, SZ and AG stands for Cash Conversion cycle, average payment period, inventory turnover, average collection period, leverage, Size of firm and age of firm, ROA: Return on asset, ROE: Return on equity, EPS: Earning per share

Table 5 shows the results of 2 nd regression equation of this study. This model tends to find the impact of WCM of FP of firms, however in this model the FP is observed on the basis of Return on equity (ROE). Moreover, WCM (CCC, APP, ITO and ACP) is same as we observed in the first model of the study. The above table depicts significant F-Stat 10.8822 and $\mathrm{P}$ values. Furthermore, the regression summary shows the $\mathrm{R}^{2} 0.3178$ or $31.78 \%$. It simply shows that the WCM (CCC, APP, ITO and ACP) creates $31,78 \%$ impact on the FP (ROE) of firms. The constant value denotes the insignificance which confirms that there are no additional components which could affect the dependent variable. The results are nearly related to the study of (Qureshi, 2014; Ali, 2011; Sharma and Kumar, 2011).

Table 6: Regression Model-III Summary

\begin{tabular}{lcc}
\hline \multicolumn{1}{c}{ Independent Variable } & Coefficient & P value \\
\hline CCC & -0.006 & $0.0967 *$ \\
APP & -0.1609 & $0.1932^{*}$ \\
ITO & -0.5971 & $0.0061^{* *}$ \\
ACP & 0.4821 & $0.0387 * *$ \\
LEV & 46.1812 & 0.1523 \\
SZ & 26.7443 & 0.8109 \\
AG & 2.9873 & 0.9984 \\
Constant & -903.617 & 0.1567 \\
$\mathrm{R}^{2}$ & 31.22 & F-Statistics \\
Adj: $\mathrm{R}^{2}$ & 30.43 & Probability (F-Statistics) 0.005 \\
\hline
\end{tabular}

** and * indicates significance at the 5\% and $10 \%$ level respectively, CCC, APP, ITO, ACP, LEV, SZ and AG stands for Cash Conversion cycle, average payment period, inventory turnover, average collection period, leverage, Size of firm and age of firm, ROA: Return on asset, ROE: Return on equity, EPS: Earning per share

Sukkur IBA Journal of Management and Business - SIJMB | Volume 5 No. 2 July - December 2018 @ Sukkur IBA University 
Table 6 shows the results of 3rd and last regression model of the study. The model summary refers the impact of WCM (CCC, APP, ITO and ACP) on FP (EPS). It consists of the significant results in the $\mathrm{p}$ value. Moreover, the $\mathrm{R}^{2}$ shows 31.22 and also significant results are observed in F-statistics of 9.142 with the Probability of 0.005 . All independent variables show the negative impact on EPS except ACP. ACP refers a positive impact on EPS which means that if company collects the debt from a/c receivables, their financial performance can be improved. These results are also observed in the studies of (Almazari, 2014 and Qureshi,2014).

\section{Conclusion}

This study concluded and measured the impact of WCM on FP of firms (Manufacturing concerns) which are listed in Pakistan stock exchange. A population size of 50 manufacturing firms was chosen which are listed is PSX over the period of 2010-2015. Moreover, those firms who have not submitted their annual financial report were skipped from this study. We have taken samples from the manufacturing sectors, we have several sub heads of manufacturing concerns labelled into various economic groups like Pharmaceutical and Bio tech, Cement, Sugar, Beverages, Automobile, Textile, oil and gas, Technology and Hardware and Industrial metal and Mining. The firms which are in above-mentioned sectors are listed in the Pakistan Stock Exchange (PSX). In this study WCM is considered as (CCC, APP, ITO and ACP) and FP referred (ROA, ROE and EPS). We have constructed three multiple regression models to measure the impact of WCM on MP/FP. We used descriptive statistics to summarise and explain the aggregate data set and we also used correlation technique to understand the relationship among the variables. Therefore, it was observed that there was no issue of multicollinearity because no variable exceeds from the .70 or $70 \%$. All three multiple regression models were statistically significant based on $\mathrm{P}$ value and F-statistics. Furthermore, it was observed that in the regression coefficient table of the first regression model CCC and APP have statistical significant and positive impact on ROA but contrary APP and ITO have a significant but negative impact on ROA. In the second regression coefficient it was seen that CCC, APP and IT have a significant and negative impact on ROE and ACP consist a significant and positive impact on ROE. In the third and last coefficient table, nearly the same results were observed as in the second model. In the third regression model, ACP has a positive and significant on EPS and CCC, APP and ITO have a negative impact on EPS. This study has some relevant findings in comparison of the previous studies of (Sharma \& Kumar, 2011; Deloof, 2003)

\section{Recommendations}

This study considers some recommendations based on its results. This study prefers to recommend that the financial managers of firms must set a best force to control the working capital variables like CCC, APP, ITO and ACP. As it was observed that apt and prompt WCM may affect the aggregate financial performance of firm.managers should look after consciously.

Sukkur IBA Journal of Management and Business - SIJMB | Volume 5 No. 2 July - December 2018 @ Sukkur IBA University 
Fall in CCC leads to increase in the FP and increase in CCC tends to decrease the FP of firm. Therefore, the ideal situation is to set an equilibrium point of CCC to manage FP appropriately.

As it was observed in all three models that ACP has a positive impact on ROA, ROE and EPS. It means that firms collect their credits from account receivable on time, they maintained a suitable aging schedule of receivable. However, if ACP may negative so it would show that firm is weak in the collection from receivables. Meanwhile, timely collections from receivable may push the firm towards better financial performance. Moreover, ITO was negative observed, it is dangerous situation for firms. It shows that firms are not active to sell the produced inventories. If company delays the inventory conversion into sale so it may leads stop in FP. Quick ITO produced more funds for firms and firm can increase their production capacity due to high demand of goods. ITO can be improved if firms generate a suitable demand, and it is possible when foreign investment and management styles show interest in the Pakistan. Our local community has proved that foreign products are more qualitative than national ones.

\section{Limitations of Study:}

The current study is limited to manufacturing sector of Pakistan and have a sample size of 50 selective firms. Hence, this study is limited to the 50 firms. The time period of this study is also limited to five years (2010-2015). Only main proxies for WCM and FP are used to find the relationship.

\section{Future Suggestions:}

This study can be broadening by taking more firms in measuring the effect of WCM. Moreover, the services sector has unique requirements of WC. So the future studies should focus on services sector by taking some more proxies for financial performance and WCM like Tobin's Q, Payables deferrals and net profit margins.

\section{References}

Abor, J. (2004), Working capital management and corporate profitability: Evidence from Ghana. LBS Management Review, 9(1), 32-45.

Ademola, O.J. (2014), Working capital management and profitability of selected quoted food and beverages manufacturing firms in Nigeria. European Journal of Accounting Auditing and Finance Research, 2(3), 10-21.

Ahmad, N., Riaz, Z., Iqbal, N. (2014), The relationship between working capital management and profitability: Evidence from Pakistan. International Letters of Social and Humanistic Sciences, (20), 14-25.

Sukkur IBA Journal of Management and Business - SIJMB | Volume 5 No. 2 July - December 2018 @ Sukkur IBA University 
Akinlo, O.O. (2011), The effect of working capital on profitability of firms in Nigeria: Evidence from General Method of Moments (GMM). Asian Journal of Business and Management Sciences, 1(2), 130-135.

Alavinasab, E. (2013), Studying the relationship between working capital management and profitability of listed companies in Tehran stock exchange. (OSociety for Business and Management Dynamic, 2(7), 01-08.

Ali, S. (2011), Working capital management and the profitability of the manufacturing sector: A case study of Pakistan's textile industry. The Lahore Journal of Economics, 16(2), 141-178.

Almazari, A.A. (2014), The relationship between working capital management and profitability: Evidence from Saudi cement companies. British Journal of Economics, Management and Trade, 4(1), 146-157.

Almazari, A., Quresi, A. (2014), The relationship between working capital management and profitability: Evidence from Saudi cement companies. British Journal of Economics, Management \& Trade, 4(1), 146-157.

Amarjit, G., Biger, N. (2010), The relationship between working capital management and profitability: Evidence from the United States. Business and Economics Journal, BEJ-(10), 2010, 6-9.

Azam, D.M., Hider, S.I. (2011), Impact of working capital management on firms' performance: Evidence from non-financial institutions of Kse-30 index. Interdisciplinary Journal Of Contemporary Research in Business, 3(5), 481492.

Bagchi, B., Khamrui, B. (2012), Relationship between working capital management and profitability: A study of selected FMCG companies in India. Business and Economics Journal, 2012(60), 1-11.

Bellouma, M. (2010), Effect of capital investment on working capital management: Evidence on Tunisan export SME. The International Journal of Finance, 22(3), 6498-6509.

Brealey, R.A., Myers, S.C. (2002), Brealey \& Myers on Corporate Finance: Capital Investment and Valuation. New York: McGraw-Hill.

Chashmsayadan, M., Aghajannashtaei, R. (2014), Evaluation the impact of working capital management on firms performance (Case study: Tehran tock exchange). Asian Journal of Research in Banking and Finance, 4(5), 27-42.

Deloof, M. (2003), Does working capital management affect profitability of Belgian firms. Journal of Business Finance and Accounting, 30(3, 4), 306-320.

Dong, H., Su, J. (2010), The relationship between working capital management and profitability: A Vietnam case. International Research Journal of Finance and Economics, 49, 59-67.

Eljelly, A.M. (2004), Liquidity-profitability tradeoff: An empirical investigation in an emerging market. International Journal of Commerce and Management, 14(2), $48-61$.

Sukkur IBA Journal of Management and Business - SIJMB | Volume 5 No. 2 July - December 2018 @ Sukkur IBA University 
Fathi, S., Tavakolli, Y. (2009), The relationship between working capital management and financial operation of the economic entities. Journal of Business Reviews, 36, 104-116.

Forghani, M., Shirazipour, M., Hosseini, A. (2013), Impact of working capital management on firms performance. Journal of Basic and Applied Scientific Research, 3(7), 943-947.

Ghosh, S.K., Maji, S.G. (2003), Working capital management efficiency: A study on the Indian Cement Industry. The Institute of Cost and Works Accountants of India. Available from: http://www.icwai.org/ icwai/knowledgebank/fm47.pdf.

Gill, A., Biger, N., Mathur, N. (2010), The relationship between working capital management and profitability: Evidence from the United States. Business and Economics Journal, 10, 1-9.

Gitman, L.J. (1994), Principles of Managerial Finance. 7th ed. London: Harper Collins. p646-652.

Gulia, R. (2014), Effects of working capital management on firms profits-evidence from the pharmaceutical sector. International Journal of Management and Social Sciences Research, (IJMSSR), 3(1), 103-107.

Haq, I.U.L., Muhammad, S., Khalid, Z., Zaheer, A. (2011), The relationship between working capital management and profitability: A case study of cement industry in Pakistan. Mediterranean Journal of Social Sciences, 2(2), 365-372.

Horne, J.C., Wachowicz, J.M. (2000), Fundamentals of Financial Management. 11th ed. New York: Prentice Hall Inc.

Kothari, C.R. (2004), Research Methodology: Methods and Techniques. New Delhi: New Age International (P) Ltd., Publishers.

Lazaridis, I., Tryfonidis, D. (2006), Relationship between working capital management and profitability of listed companies in Athens stock exchange. A Journal of Financial Management and Analysis, 19(1), 26-35.

Makori, D.M., Jagongo, A. (2013), Working capital management and firm profitability: Empirical evidence from manufacturing and construction firms listed on Nairobi securities exchange, Kenya. International Journal of Accounting and Taxation, 1(1), 1-14.

Malik, M.S., Mahumad, B. (2014), The impact of working capital management on corporate performance: A study of firms in cement, chemical and engineering sectors of Pakistan. Pakistan Journal of Commerce and Social Sciences, 8(1), 134-148.

Mansuri, E., Joriah, M. (2012), The effect of working capital management on firm's profitability: Evidence from Singapore. Interdisciplinary Journal of Contemporary Research in Business, 4, 472-486.

Mobeen, A.H., Ali, L., Abdu, R., Akram, M. (2011), Impact of working capital management on profitability and market valuation of Pakistani firms. European Journal of Economics, Finance and Administrative Sciences, 32, 48-54.

Sukkur IBA Journal of Management and Business - SIJMB | Volume 5 No. 2 July - December 2018 @ Sukkur IBA University 
Mukhopadhyay, D. (2004), Working capital management in heavy engineering firms A case study. Available from: http://www. myicwai.com/knowledge bank/fm48.

Napompech, K. (2012), Effects of working capital management on the profitability of Thai listed firms. International Journal of Trade, Economics and Finance, 3(3), 227-232.

Naveed, A., Nadeem, M., Hammad, N. (2014), Impact of working capital on corporate performance: A case study from cement, chemical and engineering sectors of Pakistan. Arabian Journal of Business and Management Review (Oman Chapter), 3(7), 12-22.

Nazir, M.S., Afza, T. (2008), On the factors determining working capital requirements. Proceedings of ASBBS, 15(1), 293-301.

Nazir, M.S., Afza, T. (2009), Impact of aggressive working capital management policy on firms' profitability. IUP Journal of Applied Finance, 15(8), 19-30.

Nobanee, H., Abdul, L.M., Aslhajjar, M. (2011), Cash conversion cycle and firm's performance of Japanese firms. Asian Review of Accounting, 19(2), 147-156.

Nwankwo, O., Osho, G.S. (2010), An empirical analysis of corporate survival and growth: Evidence from efficient working capital management. International Journal of Scholarly Academic Intellectual Diversity, 12(1), 1-13.

Odi, N., Solomon, O. (2010), An empirical analysis of corporate survival and growth. Evidence: From Efficient Working Capital Management, 12(1), 1-13.

Padachi, K. (2006), Trends in working capital management and its impact on firms performance. An analysis of Mauritanian small firms. International Review of Business Research Papers, 2(2), 45-58.

Pouraghajan, E. (2012), The relationship between capital structure and firm performance evaluation measures: Evidence from the Tehran stock exchange. International Journal of Business and Commerce, 1(9), 166-181.

Qureshi, M.A. (2014), Relationship of operating cycle and firm's returns: Cases from manufacturing firms listed in KSE Pakistan. International Journal of Advance Research, IJOAR, 2(2), 1-10.

Raheman, A., Nasr, M. (2007), Working capital management and profitability-case of Pakistani firms. International Review of Business Research Papers, 3(1), 279300.

Rajesh, M., Reddy, V. (2011), Impact of working capital management on firms' profitability. Global Journal of Finance and Management, 3(1), 151-158.

Sarniloglu, F., Demirgunes, K. (2008), The effect of working capital management on firm profitability: Evidence From Turkey. International Journal of Applied Economics and Finance, 10(2), 44-50.

Sen, M., Eda, O. (2009), Relationship between efficiency level of working capital management and return on total assets is ISE. International Journal of Business and Management, 4(10), 109-114.

Sukkur IBA Journal of Management and Business - SIJMB | Volume 5 No. 2 July - December 2018 @ Sukkur IBA University 
Sharma, A.K., Kumar, S. (2011), Effect of working capital management on firm profitability: Empirical evidence from India. Global Business Review, 12(1), 159-173.

Shaw, B. (2006), Are Mark Able Book About Human Behavior and A Worldwide Best Seller.

Singh, K., Asress, F.C. (2011), Determining working capital solvency level and its effect on profitability in selected Indian manufacturing firms. International Journal of Research in Commerce, Economics and Management, 1(2), 52-57.

Taani, M.H. (2011), The effect of financial ratios, firm size and cash flows from operating activities on earnings per share: (An Applied Study: On Jordanian Industrial Sector). International Journal of Social Sciences and Humanity Studies, 3, 197-205.

Taleb, G.A., Zoued, A.N., Shubiri, F.N. (2010), The determinants of effective working capital management policy: A case study on Jordan. Interdisciplinary Journal of Contemporary Research in Business, 2(4), 248-264.

Uremadu, J.A., Egbide, B., Enyi, P.E. (2012), Working capital management, liquidity and corporate profitability among quoted firms in Nigeria: Evidence From the productive sector. International Journal of Academic Research in Accounting, Finance and Management Sciences, 2(1), 80-97.

Uyar, A. (2009), The relationship of cash conversion cycle with firm size and profitability: An empirical investigation in Turkey. International Research Journal of Finance and Economics, 24, 186-193.

Vural, G., Sokmen, A.H., Cetenak, E.H. (2012), Effects of working capital management on firm's performance: Evidence from Turkey. International Journal of Economics and Financial Issues, 2(4), 488-495. 